\title{
Proefschrift
}

\section{The use of the Objective Clinical Examination (OSCE) in dental education}

Schoonheim-Klein ME. The use of the Objective Clinical Examination (OSCE) in dental education. Universiteit van Amsterdam, 6 juni 2008. Promotoren: prof. dr. U. van der Velden (Amsterdam) en prof. dr. C.P.M. van der Vleuten (Maastricht); co-promotor: prof. dr. J. Hoogstraten (Amsterdam).152 pagina's. ISBN:978-90-6464-237-1.E-mail:m.schoonheim@acta.nl

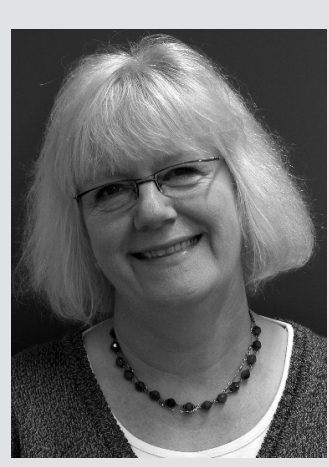

Naam:

Meta Schoonheim-Klein

Opleidingen

1973

Afgestudeerd als tandarts aan de Rijksuniversiteit Utrecht

1974

Rotating internship Eastman Dental Centre Rochester

NY USA Certificate

$1975-1978$

Studie Psychologie Vrije Universiteit Amsterdam, propedeuse

2004

Mediator, geregistreerd

Onderwijskundige werkzaamheden

1974-1982

Klinisch docent Kindertandheelkunde

1988

Klinisch docent Algemene tandheelkunde en Parodontologie

1997

Staftrainingen over tandheelkundig onderwijs en beoordelen

2003

Tutorresearch voor bachelor- en masterstudenten

2006

Consultant dental education in USA en Letland

Professionele werkzaamheden

1977-1998

Algemeen Tandheelkundige praktijk

$1977-2000$

Jaarhoofd en coördinator onderwijspraktijken

2002-2003

Lid curriculumcommissie

2008

Lid Opleidingscommissie

2004-2008

Promotietraject

Huidige functie

Universitair docent en klachtenfunctionaris, met als taken kwaliteit van onderwijs en zorg, onderwijs in evidence based dentistry en klinische parodontologie en onderzoek naar tandheelkundig onderwijs. 


\section{Inleiding}

De laatste decennia was men binnen het tandheelkundig onderwijs steeds minder tevreden over de methoden van toetsing van klinische competenties. Vaak werden alleen motorische vaardigheden getoetst, zonder de communicatie met de patiënt en de professionaliteit te toetsen. Misschien was de Objective Structured Clinical Examination (OSCE) een toets om deze manco's op te lossen? De OSCE is een competentietoets waarbij de student rouleert langs verschillende (test)stations. De OSCE wordt gebruikt voor het toetsen van klinische competenties in een gesimuleerde omgeving. Omdat in het medisch onderwijs de OSCE een goede competentietoets bleek, is sinds een tiental jaren de OSCE dan ook ingevoerd in het tandheelkundig onderwijs. Uit literatuuronderzoek bleek echter dat evidence voor de waarde van de OSCE in tandheelkundig onderwijs (vooralsnog) erg mager is. Daarom was het doel van dit proefschrift de bruikbaarheid van de OSCE te bestuderen binnen de toetsing van klinische competenties in het tandheelkundig onderwijs.

\section{Onderzoek}

In Hoofdstuk 1 van dit proefschrift wordt een model van Van der Vleuten gepresenteerd om de bruikbaarheid (utiliteit) van toetsingsmethoden te testen. Dit model is gebaseerd op vijf aspecten: de toets moet valide (V), betrouwbaar $(\mathrm{R})$ en voor de betrokkenen acceptabel (A) zijn. De toets moet uitvoerbaar en kosten effectief (C) zijn en het leergedrag moet positief worden beïnvloed, ook wel genoemd het educatieve effect (E) van de toets. Utiliteit $(\mathrm{U})=\mathrm{A} \times \mathrm{E} \times \mathrm{V} \times \mathrm{R} \times \mathrm{C}$. De bruikbaarheid van methodes van toetsing hangt af van het evenwicht tussen deze aspecten.

De onderzoeksvragen betroffen derhalve:

- Acceptatie van de implementatie van een dergelijke onderwijsverandering.
- Het effect van de OSCE op het leren van de student.

- De vraag, als onderdeel van validiteit, welke normering de meest betrouwbare beslissingen geeft voor slagen en zakken.

- De bias, de verstorende factoren voor de validiteit, zoals de moedertaal van elders geboren studenten, het geslacht en de stress die een dergelijke toets veroorzaakt.

- De betrouwbaarheid van de toets.

Om deze onderzoeksvragen te kunnen beantwoorden zijn vijf studies uitgevoerd. Er werden kwalitatieve en kwantitatieve methoden gebruikt. Met behulp van vragenlijsten werden staf- en studentevaluaties uitgevoerd voor de acceptatiestudie. Om het effect te meten van de OSCE op het leren werden twee groepen studenten vergeleken. De ene groep werd getoetst door een schriftelijk examen, de andere door een OSCE. Voor de betrouwbaarheidsstudies werden statistische analyses uitgevoerd van de OSCE-scores met o.a. de generaliseerbaarheidstheorie. Het effect van de moedertaal van de studenten tandheelkunde werd geanalyseerd met behulp van vragenlijsten om te onderzoeken of studenten met een andere moedertaal nadeel ervaren bij het doen van de OSCE vanwege hun niveau van taalbegrip en taalbeheersing.

Ten slotte werden twee normeringsmethoden vergeleken om te bepalen welke van deze het optimale instrument is om betrouwbare beslissingen te nemen over slagen en zakken.

\section{Conclusies}

De opvallendste conclusies waren:

- Het leren van de student blijkt door deze praktische toetsvorm meer bevorderd te worden dan door een schriftelijke toets. Ook hier bleek: assessment drives learning. 
- Als voorwaarde voor betrouwbare beslissingen bij een summatieve OSCE moeten minstens 20 stations worden opgenomen. De validiteit zal elke keer voor elke OSCE weer vastgesteld moeten worden.

- Wat betreft de validiteit blijken een andere moedertaal en slecht taalbegrip en -beheersing een negatief effect te hebben op de scores van de OSCE. Het verlengen van de tijdsduur voor de stations bleek geen invloed te hebben op de scores van deze allochtone studenten. Ook geslachtskenmerken vormen een bias: net als in andere onderwijsvelden scoren ook in de tandheelkundige OSCE vrouwelijke studenten hoger dan mannelijke studenten.

- Studenten gaven aan veel stress te ervaren bij deze toets. Later onderzoek heeft aangetoond dat de mate van stress in de OSCE de prestaties niet beïnvloedt.

- Hoewel de taalvaardigheid, de stress en geslachtseffecten nog meer aandacht behoeven, is de OSCE educatief valide en goed geaccepteerd.

- Wat betreft de normeringsmethode blijkt de Borderline Regressie methode met vertrouwen te kunnen worden toegepast om de zak/slaag-beslissingen te nemen van OSCEs.

Samenvattend kan in antwoord op de algemene onderzoeksvraag worden geconcludeerd dat de tandheelkundige OSCE een objectieve, betrouwbare en valide methode is om klinische competenties te toetsen, inclusief communicatieve vaardigheden.

\section{Aanbevelingen voor de onderwijspraktijk}

- De OSCE blijkt een goede competentietoets om te beslissen of de student bekwaam is om te starten met de behandeling van meer complexe tandheelkundige patiënten. De tandheelkundige OSCE blijkt een toets in de Shows how-categorie binnen de piramide van Miller. De studenten kunnen laten zien dat zij de basiscompetenties meester zijn.

- De OSCE, inclusief de Borderline Regressie normeringsmethode, zou in andere tandheelkundige opleidingen in hun competentiegerichte toetsingsprogramma opgenomen moeten worden, met als doel het leren van de student te bevorderen, de kwaliteit van de opleiding te bevorderen en die van de patiëntbehandeling te waarborgen.

\section{Toekomstig onderzoek}

Verder onderzoek is nodig naar het gebruik van de beoordeling en toetsing in de kliniek tijdens de patiëntbehandeling: de categorie Does: de top van de piramide van Miller. De ontwikkeling van goede performance assessment, toetsing op de werkplek, met onderzoek naar de validiteit en betrouwbaarheid en haalbaarheid is net als bij het medisch onderwijs ook bij het tandheelkundig onderwijs de volgende stap in het onderzoek. 